\title{
Sustainable development and cross-disciplinary research education: Challenges and opportunities for learning
}

\author{
Malin Mobjörkk ${ }^{*_{1}}$, Camilla Berglund ${ }^{2}$, Mikael Granberg 3 ,4, Magnus Johansson ${ }^{3,4}$ \\ ${ }^{1}$ Stockholm International Peace Research Institute, SIPRI, Sweden; ${ }^{2}$ School of Humanities, \\ Education and Social Sciences, Örebro University, Sweden; ${ }^{3}$ The Centre for Societal Risk Research, \\ Karlstad University, Sweden; ${ }^{4}$ The Centre for Natural Hazards and Disaster Science (CNDS), \\ Uppsala University, Sweden
}

It is widely accepted that cross-disciplinarity influences education in issues of sustainability and sustainable development. However, despite a large body of research on cross-disciplinarity, less attention has been given to how it shapes research education. Research education is a formative phase in a researcher's intellectual development and this article considers the whole research education process, including both its formal and informal aspects. It explores this arena and builds on the experiences of $\mathrm{PhD}$ candidates engaged in research education characterised by cross-disciplinarity in the realm of sustainable development. Drawing on pedagogical research on socialisation, this article examines how research education is organised in four research milieus and the experiences of $\mathrm{PhD}$ candidates pursuing their education in these learning contexts. The aim is to provide insights into how these research milieus can facilitate future cross-disciplinary research education on sustainable development. The analysis finds that in research milieus that provide courses and seminars about cross-disciplinarity, PhD candidates are more confident in situating their own research. The engagement of senior staff and supervisors in these activities is also key to develop a conceptual apparatus and building the capacity to interact with different disciplines and practitioners. Furthermore, the findings show the importance of communicating about cross-disciplinarity throughout the research education process, starting when $\mathrm{PhD}$ candidates are recruited and supervisors are appointed.

Keywords: sustainable development, research education, cross-disciplinary, interdisciplinary, transdisciplinary

\section{SUSTAINABLE DEVELOPMENT AND THE GROWING IMPORTANCE OF CROSS-DISCIPLINARITY}

Education for Sustainable Development (ESD) is commonly understood as education that encourages changes in knowledge, skills, values and attitudes to enable a more sustainable and just society for all ... The concept of ESD was born from the need for education to address the growing environmental challenges facing the planet. In order to do this, education must change to provide the knowledge, skills, values and attitudes that empower learners to contribute to sustainable development. (Leicht, Heiss \& Byun, 2018, p. 7)

Research on sustainable development is challenge-driven and often utilises cross-disciplinary research approaches (Thompson Klein, I996; 2004; 20I4; Hirsch Hadorn, Bradley, Pohl, Rist \&

*Correspondence: malin.mobjork@sipri.org

Artiklar och reflektioner är kollegialt granskade. Övriga bidragstyper granskas av redaktionen. Se https://hogreutbildning.se ISSN 2000-7558

(C)2020 Malin Mobjörk, Camilla Berglund, Mikael Granberg and Magnus Johansson. This is an Open Access article distributed under the terms of the Creative Commons Attribution-NonCommercial 4.0 International License (https://creativecommons.org/licenses/by-nc/4.0/), allowing third parties to share their work (copy, distribute, transmit) and to adapt it, under the condition that the authors are given credit, that the work is not used for commercial purposes, and that in the event of reuse or distribution, the terms of this license are made clear.

Citation: Mobjörk, M., Berglund, C., Granberg, M. \& Johansson, M. (2020). «Sustainable development and cross-disciplinary research education: Challenges and opportunities for learning", Högre utbildning, 10(1), 76-89. https://doi.org/10.23865/hu.v10.1942 
Wiesmann, 2006; Lang, Wiek, Bergmann, Pim, Moll, Swilling \& Thomas, 20I2; Brandt, Ernst, Gralla \& von Wehrden, 2013). There is growing recognition that complex environmental and social challenges 'require a different approach to education and capacity building' (O'Brien et al. 2013, p. 48). Cross-disciplinarity is called for as a response to this perceived need of change in research and higher education and is based on the idea that knowledge processes should contribute to more sustainable societies through economic, technological and institutional transformations (Schneider \& Rist, 20I3; Popa, Guillermin \& Dedeurwaerdere, 20I4; Leicht et al., 20I8). This influences the higher-education learning context on all levels (Johansson, Sternudd \& Ferreira, 20I5).

Cross-disciplinary research comes in different forms and three major types have been identified: multi-, inter- and transdisciplinary (Mobjörk, 20Io; Kelly et al., 20I9). They predominately differ in terms of level of integration and forms of collaboration. Importantly, a common feature in cross-disciplinarity is the expectation to transcend disciplinary boundaries in dealing with complex challenges such as sustainable development (Thompson Klein, 1996; Schmidt, 2008; Scholz \& Steiner, 20I5). Hence, cross-disciplinarity also includes a critique of modern science and education, especially the tendency towards specialisation and detachment from real-life experiences (Hirsch Hadorn et al., 2006; Schmidt, 2008). Accordingly, education based on cross-disciplinary approaches challenges research and higher education by questioning disciplinary structures (Boden, Borrego \& Newswander, 20II) and by fostering new skills and competences among students, lecturers and researchers (Lang et al., 20I2; Muhar, Visser \& van Breda, 20I3). This creates new learning contexts.

There has been substantive research examining cross-disciplinary research processes on sustainability. This research has most often focused on senior researcher experiences (see e.g. Beland \& Westholm, 20I4; Guimaraes, Mckee, Lima \& Denthino, 20I4; Mattor et al., 20I4; Binder, Absenger-Helmli \& Schilling, 20I5), but some research has also focused on the experiences and challenges perceived by $\mathrm{PhD}$ candidates (Enengel et al., 2012; Haider et al., 2017). These self-reflective analyses contribute to sharing valuable experiences. As research education is a formative phase in a researcher's social, intellectual and academic development (Felt, Igelsböck, Schikowitz \& Völker, 20I3; Gardner, Jansujwicz, Hutchins Cline, \& Levesque, 20I4) but has received less attention in research on cross-disciplinarity, we argue that in-depth studies of $\mathrm{PhD}$ candidates' experiences of cross-disciplinary learning contexts deserve greater attention. We also argue that analysing research education might benefit from including pedagogical research on socialisation processes in cross-disciplinary settings as well as from $\mathrm{PhD}$ candidates' experiences of different learning contexts (Mitrany \& Stokols, 2005; Graybill et al., 2006; Gaya \& BrydonMiller, 20I7).

This article examines how cross-disciplinary research education in the realm of sustainable development is organised, pursued and experienced in four learning contexts. We focus on the whole research education process including both its formal and informal aspects. The four learning contexts investigated all focus on sustainability research but differ in terms of organisational setting and involve different approaches to cross-disciplinarity. This diversity mirrors the context that research education on sustainability is pursued in. Through analysing these four learning contexts and the experiences of $\mathrm{I} 4 \mathrm{PhD}$ candidates, this article contributes with insights into how cross-disciplinary research milieus can facilitate research education and learning that is pivotal in fostering the next generation of researchers and lecturers within the field of sustainable development.

In the next section, we provide a brief overview of the socialisation of $\mathrm{PhD}$ candidates in cross-disciplinary learning contexts and outline our analytical framework. The third section 
introduces the empirical data, i.e. the four learning contexts examined. The fourth and fifth sections present the analysis, starting with the four learning contexts and followed by the $\mathrm{PhD}$ candidates' experiences. The analysis is structured around three thematic areas: I) the initiation and introductory phase; 2) learning, arenas and networks; and 3) supervision and the research education context. In the final section, we discuss our findings and key recommendations aimed at improving research education in cross-disciplinary learning contexts which will be of benefit to education for sustainable development.

\section{THE THEORETICAL PERSPECTIVE: SOCIALISATION}

Research education is a formative phase in a researcher's social, intellectual and academic development (Mitrany \& Stokols, 2005; Graybill et al., 2006; Gardner et al., 20I4; Felt et al., 2013). This phase, known as socialisation, involves the process through which an individual adopts the values, skills, attitudes, norms and knowledge needed for becoming a member of a given organisation (Gardner et al., 20I4). Gardner et al. (20I4) outline three core demands in the socialisation process of graduate students in general: knowledge acquisition ${ }^{\mathrm{r}}$, involving cognitive and tacit skills for the chosen profession; investment, referring to the development of identity and commitment; and involvement, referring to participation and the development of a professional role. The department and supervisors play a significant role in these processes (Sonesson \& Lindberg-Sand, 2016).

Many challenges that $\mathrm{PhD}$ candidates face during the socialisation process are generic, i.e. the challenges arise irrespective of learning context. However, earlier research has demonstrated that some challenges are more prominent in cross-disciplinary contexts compared to monodisciplinary contexts (Boden et al., 2oII; Bridle, Vrieling, Cardillo, Araya \& Hinojosa, 2013; Felt et al., 20I3; Gardner et al., 20I4). As learning contexts focusing on sustainable development are often characterised by cross-disciplinarity they, accordingly, also face additional challenges on socialisation. Boden et al. (20II), for instance, argue that the 'organization structure lies at the heart of many of the challenges' (p. 4) and that cross-disciplinary education, irrespective of level, needs to span across disciplinary and organisational borders. A key difference between disciplinary and cross-disciplinary environments, therefore, is the organisational setting. Here, it is relevant to reflect on what constitutes a discipline. Thompson Klein (1996) describes a discipline as delineated by differences in theories, methods and conceptual frameworks, as well as by its organisational, social and cultural dimensions. Similarly, Gardner et al. (2014) emphasise that a discipline provides history, a set of norms, practices and values, and a sense of identity, together with a set of epistemological tools and mindsets. Disciplines are not static; rather, they develop over time. Nevertheless, what at a specific time and cultural context is perceived as a discipline shapes the organisational setting. A key feature of cross-disciplinarity is this lack of organisational setting. Several researchers have argued that this is crucial in understanding the challenges of crossdisciplinary research education (Boden et al., 20II; Muhar et al., 20I3; Gardner et al., 20I4). As a consequence, $\mathrm{PhD}$ candidates focusing on sustainable development in cross-disciplinary settings, to a larger degree than mono-disciplinary settings, have to adopt strategies for positioning themselves in multiple arenas (Felt et al., 2013).

However, cross-disciplinary research education not only challenges the established academic system (Boden et al., 20II; Felt et al., 20I3); several researchers also argue that it poses specific challenges for the individual (Lang et al., 20I2; Muhar et al., 20I3; Augsburg 20I4; Kemp \& Nurius, 20I5). These

1 Instead of the Gardner et al. concept of 'knowledge acquisition', we use the term 'learning' in this article. 
challenges include: contextualising complex and multilevel issues; engaging with different disciplines and with practitioners; being able to think holistically; and using theories from multiple disciplines in the development of integrative conceptual frameworks (Kemp \& Nurius, 20I5; Augsburg, 20I4). One could certainly discuss how unique these expectations are for cross-disciplinary researchers but, as Augsburg (2014) argues, the expectations of cross-disciplinary researchers seem to be particularly high, which is also explained by the expectations of cross-disciplinarity - to deal with, and even solve, pressing social challenges like sustainable development.

This study is informed by pedagogical research on socialisation in the context of crossdisciplinary research education and in the realm of sustainable development. The research education context and the supervision of $\mathrm{PhD}$ candidates influences the socialisation process of these $\mathrm{PhD}$ candidates, their learning and their ability to develop competences and skills in conducting cross-disciplinary research. Against this backdrop, we have developed an analytical framework to guide our analysis of research education in four cross-disciplinary learning contexts in the realm of sustainable development. Three thematic areas have been identified from the literature that we used when structuring our analysis:

I. The initiation and introductory phase - focusing on preparedness, motivation and expectations (cf. Boden et al., 20II; Muhar et al., 20I3; Felt et al., 20I3; Gardner et al., 20I4). We consider if, and how, $\mathrm{PhD}$ candidates get acquainted with issues of cross-disciplinarity already in the early phases of their research education and if there are any reflections on what this might entail for research education and for individual $\mathrm{PhD}$ candidates. Key aspects are whether, and how, cross-disciplinarity is introduced and communicated in the introductory phases of research education, and how cross-disciplinarity is understood among $\mathrm{PhD}$ candidates.

2. Learning, arenas and networks - focusing on how knowledge is provided in the research education context in terms of courses and seminars. We consider if $\mathrm{PhD}$ candidates are introduced to conceptual and methodological discussions of cross-disciplinarity and if, and how, this connects to learning. We also focus on the cognitive skills acquired through education in methods and theory (Gardner et al., 20I4).

3. Supervision and the research education context - focusing on the appointment of supervisors, supervisor experiences of cross-disciplinarity and the character of research education in terms of cross-disciplinarity (cf. Lang et al., 20I2; Muhar et al., 2013; Augsburg, 20I4; Kemp $\&$ Nurius, 2015).

\section{THE EMPIRICAL DATA}

The empirical data consists of the responses to a free text survey from the directors of four cross-disciplinary research education contexts in the realm of sustainable development and semi-structured interviews with $\mathrm{I}_{4} \mathrm{PhD}$ candidates enrolled at them. These four research education contexts were chosen for two reasons. First, some key staff at one of the universities involved in the study had initiated a developing process on how to improve its research education in the area of sustainable development. To analyse the relevant learning contexts at this university was, hence, of interest. Second, in order to expand the learning contexts examined, we also wanted to analyse experiences in other research education contexts which could, presumably, be different. Choosing the two additional research milieus, we aimed to examine research education contexts reflecting the heterogeneity of cross-disciplinary approaches in the realm of research on sustainable development. Taken together, the four research education contexts examined, hence, 


\section{Malin Mobjörk et al.}

involve different cross-disciplinary approaches, spanning multi-, inter-, and transdisciplinarity and different areas of sustainable development.

The survey to the four directors included six broad questions that were answered in writing and provided brief background information about each of the research milieus, which could be used analytically with the results from the interviews. The focus of the survey was on the background, development and organisation of the research education, and included more specific questions on the recruitment of $\mathrm{PhD}$ candidates, the appointment of supervisors, and the existence of courses or seminars on cross-disciplinarity. As such, the survey provided information on all three thematic areas of the analytical framework. The quality of the survey replies was good overall across the four research milieus (Appendix I provides a brief overview of the four milieus).

The primary data used in the analysis consisted of I4 semi-structured interviews with $\mathrm{PhD}$ candidates (see Appendix II). We sent out an invitation to the $\mathrm{PhD}$ candidates who were enrolled in, or recently finished, the research education in the four research milieus, to participate in the study and interviewed those who replied positively. This means that the interviewed $\mathrm{PhD}$ candidates had a willingness to share experiences, which also serves the purpose of this explorative study. Three to four $\mathrm{PhD}$ candidates per research milieu were interviewed and the $\mathrm{PhD}$ candidates were in different phases of their research education at the time of the interview. Seven of the interviewed PhD candidates were about halfway through their research education, four had recently completed their PhDs, and three had started a year prior to the interview. The interviews were conducted face to face, by telephone or via Skype, and by the same interviewer. The interviews lasted 30-6o minutes. The time frame was linked to a satisfaction in the conversation. All interviews were recorded and transcribed. Quotes from the interviews were translated into English when needed. The interviews were labelled 'PhD number', with a reference to the line in the transcript referred to. Information in the quotes that could enable identification has been removed. As the authors of this article include senior researchers currently supervising, or who have formerly supervised, some of the interviewed $\mathrm{PhD}$ candidates, the power relations between interviewer and interviewees was discussed when planning the project. To enable the $\mathrm{PhD}$ candidates to speak openly and confidently, and to ensure their confidentiality, the interviews were conducted by a junior researcher. The same person transcribed the interviews, and the transcription was read and analysed by the junior researcher together with a senior researcher who had no relation to the PhD candidates or the research education milieus. The interviews were carried out successfully, with no sign that the candidates felt inhibited.

The empirical data used in this analysis is not intended to represent a thorough comparative analysis of the four learning contexts; instead, our approach was explorative and aimed to examine the organisation of research education and the experiences of $\mathrm{PhD}$ candidates, and how those can facilitate or hinder learning. This enabled us to discover similarities and differences across the four learning contexts and identify critical factors in the formal and informal organisation of cross-disciplinary research education.

\section{THE FOUR RESEARCH AND LEARNING CONTEXTS}

The four research education contexts (labelled milieus A-D) examined in this article come from three different universities in Sweden and Germany, and their origins illustrate the diversity of cross-disciplinary research education. Milieus A and B were established with the aim of obtaining sufficient research capacity to offer research education. The researchers and $\mathrm{PhD}$ candidates linked to milieu A represent at least eight different disciplines, and the corresponding figure for milieu $\mathrm{B}$ is three. This can be compared with milieu $\mathrm{C}$, which is part of a large department 
but characterised by a small number of senior researchers and a comparatively large number of $\mathrm{PhD}$ candidates within two different disciplines. Milieu D is a research project with external funding for a specific period of time, representing five different disciplines (for an overview, see also Appendix I).

These research education contexts align themselves with different types of cross-disciplinary research on and for sustainable development and have acted differently in the recruitment of $\mathrm{PhD}$ candidates. Milieu A describes itself primarily as being multidisciplinary, which mirrors its origin, i.e. to pool enough competence from individual researchers and small research groups to achieve a critical mass supporting research education. The supervisors and $\mathrm{PhD}$ candidates remain in their disciplines. No discussions were conducted with $\mathrm{PhD}$ applicants during the recruitment process about the multidisciplinary context they would be situated in. Similarly, neither milieu $\mathrm{B}$ nor $\mathrm{C}$, which align themselves with being interdisciplinary and the latter also with transdisciplinary research, discussed the cross-disciplinary context during the recruitment process. However, milieu $\mathrm{B}$ is an interdisciplinary research environment with senior researchers from different disciplinary backgrounds that, together with the $\mathrm{PhD}$ candidates, belong to an emerging discipline institutionalised at the university. Only the research project in milieu D explicitly discussed its cross-disciplinary character during the recruitment process. Four $\mathrm{PhD}$ candidates were recruited. The recruitment team explained to the candidates that they were going to join an interdisciplinary context with expectations of cross-disciplinary collaboration and participation in interdisciplinary activities.

There were also significant differences across the four research education contexts regarding to what extent, and how, arranged activities included explicit conceptual and methodological thinking about cross-disciplinarity. In milieu A, no courses or seminars have explicitly addressed cross-disciplinarity. In milieu B, courses and seminars have been influenced by interdisciplinarity. The interdisciplinary approach characterising these activities has primarily been practiceoriented, i.e. influencing the network with diverse academic departments and societal actors. No courses or seminars have explicitly addressed conceptual or methodological reflections on cross-disciplinarity. This is also the case in milieu C. Here, the cross-disciplinary activities have mostly been held in interaction with actors outside academia and conferences mirroring the transdisciplinary profile. The research project in milieu D adopted a different approach compared to the other three and offered courses that explicitly addressed cross-disciplinarity. Besides providing two courses on cross-disciplinary concepts and tools, it organised seminars and project conferences addressing inter- and transdisciplinary studies. At these seminars and conferences, both the project's senior researchers and its $\mathrm{PhD}$ candidates participated. The $\mathrm{PhD}$ candidates also attended other inter- and transdisciplinary conferences.

Regarding how supervisors were appointed, we observed diverse approaches across the four research milieus. Furthermore, we noticed substantial differences in how engaged the supervisors were in the cross-disciplinary ambition. In milieus $\mathrm{A}$ and $\mathrm{C}$, the supervisors have a disciplinary background in the discipline that the $\mathrm{PhD}$ candidates will receive their $\mathrm{PhD}$ in. In milieu A, most $\mathrm{PhD}$ candidates also have a co-supervisor, but the main supervisor and co-supervisor come from the same discipline. In the appointment of supervisors, no attention was given to whether the supervisor had any experience of cross-disciplinarity, and some supervisors have not been actively involved in the research milieu. This can be compared with milieus B and D, where the $\mathrm{PhD}$ candidates have at least two supervisors, each from a different discipline. This is the result of a deliberate choice by the directors of the research milieus, aimed at strengthening the cross-disciplinary approach. Interestingly, this approach was taken despite the $\mathrm{PhD}$ 
candidates in milieu $\mathrm{D}$ received their $\mathrm{PhD}$ degree within their subject area of origin. In milieu $\mathrm{B}$, the $\mathrm{PhD}$ degree was awarded in a newly-established discipline.

\section{THE PHD CANDIDATES' EXPERIENCES}

\section{The initiation and introductory phase}

The reasons $\mathrm{PhD}$ candidates give for starting research education vary, but a key driver is curiosity originating from experiences either from work outside academia or from previous research or graduate studies. They often describe their enrolment as a result of chance, and only a few $\mathrm{PhD}$ candidates describe their motives in terms of a career choice. For most, the topic of their thesis has developed from an earlier graduate paper or from work experience within or outside academia. The PhD candidates have taken different approaches to sustainable development in their theses, such as power, governance, organisation, economic development, lifestyle changes, risk management, architecture and infrastructure. These are related to a range of diverse topics, for example: participatory methods for disaster risk reduction; reindeer herding, governance and climate change adaptation; architectural design and blue-green infrastructure; downshifting for sustainable development; integration of uncertainties in decision-making for water management; and economic consequences of natural disasters. The intersection of societal and environmental challenges attracted many of the $\mathrm{PhD}$ candidates. One common objective has been to bridge academic research and practice, and for some $\mathrm{PhD}$ candidates this involves collaboration with those affected by the problem. This is exemplified in the following quote: 'I decided to do my $\mathrm{PhD}$ thesis on something that engages with the population, something that actually reaches people affected and includes them in the whole process.' $\left(\mathrm{PhD}_{2}, 274-276\right)$

Two pivotal expectations behind the $\mathrm{PhD}$ candidates' research have been to assess and improve research tools and contribute to social benefits. Desirable outcomes mentioned include theoretical, methodological and communication tools for handling issues of complexity and contributing to social transformation. Some $\mathrm{PhD}$ candidates described research tools as valuable and necessary for achieving social benefits, while others regarded them as important for a future career within or outside academia.

Motives were also related to what the $\mathrm{PhD}$ candidates initially thought about, and reflected on, in terms of cross-disciplinarity. Some $\mathrm{PhD}$ candidates expressed deliberate reasons for pursuing research education in a cross-disciplinary environment: 'I never asked myself that question, because I worked here, and if I were to get a doctorate it had to be on a cross-disciplinary theme.' (PhDio, 309I-3092)

Overall, the PhD candidates who explicitly expressed that the cross-disciplinary setting was important tended to have previous experience of cross-disciplinarity. While pre-understanding is one aspect behind satisfaction with the cross-disciplinary context, another seems to be grounded in the selection process of candidates. Of the four examined research milieus, only one (D) explicitly addressed the fact that the $\mathrm{PhD}$ candidates were going to be enrolled in a cross-disciplinary environment during the recruitment process. The four $\mathrm{PhD}$ candidates in this milieu also appeared to be satisfied and comfortable with the cross-disciplinary approach that shaped their education.

\section{Learning, arenas and networks}

Courses and seminars have the potential for creating arenas for $\mathrm{PhD}$ candidates to meet, learn, discuss and exchange ideas. The three Swedish research education milieus (A, B and D) have, to varying degrees, offered courses that address cross-disciplinary concepts and approaches. Our 
interviews showed that courses and seminars are perceived as important arenas for learning and knowledge exchange. Accordingly, courses are described as having an important influence on the development of the PhD candidates' theses. An early introduction to cross-disciplinary thinking and concepts seems to make $\mathrm{PhD}$ candidates more comfortable in discussing crossdisciplinarity and relating their work to different cross-disciplinary approaches. The $\mathrm{PhD}$ candidates that had not been given this early cross-disciplinary input described a lack of identity and joint conceptual understanding:

... we may speak the same language within this group, but I feel I lack something, and I think we all feel this. It is not like in political science where you have a common ground; you know that this concept means this, there is a theoretical basis that we are relying on and we have a common conceptual apparatus. ( $\left.\mathrm{PhD}_{4}, \mathrm{I}_{390}-\mathrm{I} 394\right)$

The same PhD candidate had a suggestion for counteracting this perceived downside:

We need a kind of forum where you actually discuss ... what cross-disciplinarity is, what sort of cross-disciplinarity we are dealing with, how we define it and how we practise it. $\mathrm{PhD}_{4}$, I395-I397)

This illustrates how research milieus play an important role in providing an arena for addressing key aspects of relevance for the research education. If it has a cross-disciplinary character, different concepts, forms and experiences of cross-disciplinarity should also inform the research education, providing the foundation for a common understanding of cross-disciplinarity in that learning context.

The interviews also showed that there is significant self-organisation of activities among $\mathrm{PhD}$ candidates. Informal seminars are the most common expression of this, but other activities have included, for example, the establishment of a network and the production of edited volumes. These activities have also, to varying degrees, involved senior researchers. These self-organised activities provide an arena for $\mathrm{PhD}$ candidates to interact, learn from each other, develop cross-disciplinary approaches and shape research education contexts. At the same time, they are considered challenging and require time and confidence: ... you have, in a way, been part of shaping the doctoral education when you have been a student yourself, and I cannot say if it has been for better or for worse.' (PhDi3, 4024-4026)

Connected to these efforts is the struggle to adapt to and handle perspectives, methods and theories from different fields and disciplines. Being enrolled in a cross-disciplinary context involves an array of research perspectives, with some possible consequences:

Maybe I am not a specialist in anything ... and it can sometimes feel like a drawback or weakness. $\left(\mathrm{PhD}_{3}, 850-854\right)$

... there's nowhere you feel you have this deep knowledge which makes you feel stable; you are always swaying a bit. This can feel troublesome, but also very exciting. (PhDi3, 4000-4002)

\section{Supervision and the research education context}

The interviews demonstrated the important role that supervisors and the research milieus play in building $\mathrm{PhD}$ candidates' confidence in cross-disciplinarity. In general, there was a positive perception about belonging to a cross-disciplinary research education context. The $\mathrm{PhD}$ candidates considered it critical to establishing and getting involved in networks within and outside 


\section{Malin Mobjörk et al.}

academia, through conferences, courses and projects. In addition, the $\mathrm{PhD}$ candidates described the research education context as an important forum for testing ideas and receiving feedback, and some expressed the larger research context as a valuable complement to their supervisors. However, lack of communication among supervisors and the cross-disciplinary setting was an issue. This was particularly the case for the $\mathrm{PhD}$ candidates in milieu A, who pursued their theses in a disciplinary context and had supervisors who were not active in the cross-disciplinary research setting.

Supervisors play a crucial role in guiding $\mathrm{PhD}$ candidates in the multifaceted cross-disciplinary environment, as well as in managing feedback from different disciplines. Hence, the different use of concepts can be a challenge in a cross-disciplinary setting and may influence supervision negatively, especially when supervisors are not involved in the cross-disciplinary setting and/or do not have experience of cross-disciplinary research:

One of my supervisors was part of this cross-disciplinary project, and was the one who got me to apply for the position. That supervisor was very decisive and had very strong opinions about how the thesis should be done, that it should be cross-disciplinary ... The other supervisor was not involved in the project but held a position in the discipline where I later defended my thesis ... and was not so positive about the cross-disciplinary approach. ( $\left.\mathrm{PhD}_{7}, 2446-2454\right)$

This addresses the importance of strategic thinking when appointing supervisors. As expressed by one $\mathrm{PhD}$ candidate, entering unfamiliar territories adds a layer of vulnerability and requires an ability to defend the chosen path: 'If you are in any way unconventional, you will be questioned, and it can be tough' (PhDi2, 3728-3729). Here, the supervisors play an important role in helping students embark on new areas of research and, in order to do this, they also need to be interested in shaping cross-disciplinary research efforts.

\section{FINDINGS AND RECOMMENDATIONS}

This article has examined the formal and informal organisation of research education in four cross-disciplinary research education contexts in the realm of sustainable development and the experiences of $\mathrm{I} 4 \mathrm{PhD}$ candidates enrolled at them. Research education is a highly formative phase for training and socialising the next generation of lecturers and researchers. As education on sustainable development, on all levels, often spans disciplinary boundaries it is shaped by different forms of cross-disciplinary approaches. To advance the education in these learning contexts we believe greater efforts should be placed on the organisational aspects of cross-disciplinary research education with a clearer focus on $\mathrm{PhD}$ candidates' experiences of their research education. While it is relevant to ask how unique these experiences are for cross-disciplinary research education or whether they are part of the process of research education more generally, we suggest, in line with previous research on cross-disciplinarity (Boden et al., 20II; Felt et al., 20I3; Gardner et al., 20I4), that the organisational setting is a decisive characteristic distinguishing cross-disciplinary settings from mono-disciplinary ones. This is also an empirical question, which may be studied in future research. Nevertheless, the experiences of the I4 $\mathrm{PhD}$ candidates interviewed in this study could inform the strategic thinking of research milieus and supervisors in terms of how to facilitate the socialisation process of cross-disciplinary research education and create positive outcomes.

Our conclusions are organised around the three thematic areas analysed. In the first, the initiation and introductory phase, the interviews indicated that cross-disciplinary issues are not sufficiently discussed at the outset. Accordingly, some $\mathrm{PhD}$ candidates have enrolled in research education without having any pre-understanding of cross-disciplinarity or the potential meaning 
of cross-disciplinarity for a future academic career. Although $\mathrm{PhD}$ candidates are responsible for getting information about the research centre or project before applying, recruiters also have a responsibility to introduce such a central topic. The interviews showed that integration of the $\mathrm{PhD}$ candidates is smoother if the cross-disciplinary approach is explicitly formulated and communicated early in the process. Explicit metacommunication about cross-disciplinarity is therefore needed and should continue throughout the research education process.

In the second thematic area, learning, arenas and networks, only one of the examined research education contexts offered courses and seminars explicitly focusing on cross-disciplinarity. The interviews showed that these courses facilitated PhD candidates' cross-disciplinary learning in terms of theoretical and methodological understanding. This meta approach to crossdisciplinarity also benefits the research education context by providing and developing common concepts. Hence, efforts to clarify conceptual and methodological issues and aspects can limit the conceptual misunderstandings observed in this study.

Another observation is that informal and self-organised activities are common. This is not a problem in itself, but it may indicate a problem if these activities are responses to a perceived lack in the ability of a research education context to address the needs of its $\mathrm{PhD}$ candidates. Selforganised activities are good from a socialisation perspective, but candidates should not be left in a void. The interviews suggested that there is a risk $\mathrm{PhD}$ candidates are left to fend for themselves too much, without sufficient support or guidance. Instead, supervisors and senior researchers should be encouraged to show interest, share experiences and provide guidance. Activities organised for and by the PhD candidates need to be strategically and systematically handled and integrated into the research education process. Offering formal courses and forums for communication lays the foundation for learning, developing a conceptual apparatus and informing a common understanding across disciplines, which benefits $\mathrm{PhD}$ candidates and their education.

In the third thematic area, supervision and the research education context, this study shows that a cross-disciplinary research setting, with its different disciplinary approaches, can be both a strength and a weakness. As such, the challenges connected to this need to be explicitly addressed by supervisors. Collaboration, inherent in much cross-disciplinary research, has the potential to build confidence. By offering good collaborative training, the foundation for successful learning may be strengthened, with positive implications for the future careers of the $\mathrm{PhD}$ candidates.

A key finding is that $\mathrm{PhD}$ candidates are more comfortable as cross-disciplinary researchers when cross-disciplinarity has been raised already in the recruitment phase and when the education specifically includes meta-communication about conceptual approaches, methodology and senior researchers' experiences related to cross-disciplinary research. Therefore, a key recommendation to the cross-disciplinary research education context is to adopt a deliberative and explicit approach, communicating cross-disciplinarity in formal courses, seminars and supervision. It is also important to facilitate informal arenas for discussion on cross-disciplinary challenges and opportunities throughout the research education process. Taken together, these steps will strengthen $\mathrm{PhD}$ candidates' learning in ways that will benefit them and future cross-disciplinary research and education on sustainable development.

\section{AUTHOR BIOGRAPHIES}

Malin Mobjörk is the Director of the Climate Change and Risk programme at Stockholm International Peace Research Institute, SIPRI. Mobjörk's research focuses on the intersection between climate change, security and development, and how policy organizations are responding to climate-related security risks. Her work also encompasses shifting notions of security and geopolitics 
linked to global environmental change. Mobjörk has a decade long experience of bridging research and policy and has also a particular interest in inter- and transdisciplinary research.

Camilla Berglund is senior lecturer in Human geography and teach in the programme Urban and Regional Planning at Örebro University. Research interest in general is the political ecology of forestry and natural resources management, with a special focus on Ethiopia.

Mikael Granberg, is professor of political science and co-director at the Centre for Societal Risk Research, Karlstad University. Granberg's main focus of research is political processes. The area mostly focused during recent years is how challenges from global climate change are handled by society. A special interest here is if and how institutionalised political practices and norms facilitates or hinders collective action. Granberg is also affiliated with the Centre for Natural Hazards and Disaster Science (CNDS), Uppsala University, as a board member, research fellow and supervisor.

Magnus Johansson is docent in risk \& environmental studies at the Centre for Societal Risk Research, Karlstad University. Within research he is focused on different aspects of learning after disasters - what we learn and what we do with that knowledge. His field as a lecturer mostly targets society's disaster risk reduction efforts and the need to integrate this with climate change adaptation. Since 2010 he has also been affiliated with the Centre for Natural Hazards and Disaster Science (CNDS), Uppsala University, as a researcher and supervisor.

\section{REFERENCES}

Augsburg, T. (2014). Becoming transdisciplinary: The emergence of the transdisciplinary individual. The Journal of New Paradigm Research, 70, 233-247.

Beland, K. \& Westholm, E. (2014). Transdisciplinarity in practice: Aims, collaboration and integration in a Swedish research programme. Journal of Integrative Environmental Sciences, 11, 155-171. DOI: 10.1080/1943815X.2014.945940

Binder, C. R., Absenger-Helmli, I. \& Schilling, T. (2015). The reality of transdisciplinarity: A framework-based self-reflection from science and practice leaders. Sustainability Science, 10, 545-562. DOI: $10.1007 / \mathrm{s} 11625-015-0328-2$

Boden, D., Borrego, M. \& Newswander, L. K. (2011). Student socialization in interdisciplinary doctoral education. Higher Education, 62, 741-755.

Brandt, P., Ernst, A., Gralla, F. \& von Wehrden, H. (2013). A review of transdisciplinary research in sustainability science. Ecological Economics, 92, 1-15.

Bridle, H., Vrieling, A., Cardillo, M., Araya, Y. \& Hinojosa, L. (2013). Preparing for an interdisciplinary future: A perspective from early-career researchers. Futures, 53, 22-32.

Enengel, B., Muhar, A., Penker, M., Freyer, B., Drlik, S. \& Ritter, F. (2012). Co-production of knowledge in transdisciplinary doctoral theses on landscape development: An analysis of actor roles and knowledge types in different research phases. Landscape and Urban Planning, 105, 106-117. DOI:10.1016/ j.landurbplan.2011.12.004

Felt, U., Igelsböck, J., Schikowitz, A. \& Völker, T. (2013). Growing into what? The (un-)disciplined socialisation of early stage researchers in transdisciplinary research. Higher Education, 65, 511-524.

Gardner, S. K., Jansujwicz, J. S., Hutchins, K., Cline, B. \& Levesque, V. (2014). Socialization to interdisciplinarity: Faculty and student perspectives. Higher Education, 67, 255-271.

Gaya, P. \& Brydon-Miller, M. (2017). Carpe the academy: Dismantling higher education and prefiguring utopias through action research. Futures, 94, 34-44. http://dx.doi.org/10.1016/j.futures.2016.10.005

Graybill, J. K., Dooling, S., Shandas, V., Withey, J., Greve, A. \& Simon, G. L. (2006). A rough guide to interdisciplinarity: Graduate student perspectives. Bioscience, 56, 757-763. 
Guimaraes, M. H., Mckee, A., Lima, M. L. \& Denthino, T. (2014). Putting transdisciplinarity into practice: A mixed mode procedure for stakeholder participation in natural resource management. Journal of Environmental Planning and Management, 58, 1-26.

Haider, L. J., Hentati-Sundberg, J., Giusti, M., Goodness, J., Hamann, M., Masterson, V. A., Meacham, M., Merrie, A., Ospina, D., Schill, C. \& Sinare, H. (2017). The undisciplinary journey: Early-career perspectives in sustainability science. Sustainability Science, 13, 191-204. DOI 10.1007/s11625-017-0445-1

Hirsch Hadorn, G., Bradley, D., Pohl, C., Rist, S. \& Wiesmann, U. (2006). Implications of transdisciplinarity for sustainability research. Ecological Economics, 60, 119-128.

Jacobs, J. A. (2013). In Defense of Disciplines: Interdisciplinarity and Specialization in the Research University. Chicago: University of Chicago Press.

Johansson, M., Sternudd, C. \& Ferreira, I. (2015). The Walkshop: A tool to integrate research on human aspects of sustainable urban design in teaching. Högre Utbildning, 5, 145-157.

Kelly, R., Mackay, M., Nash, K. L., Cvitanovic, C., Allison, E. H., Armitage, D., Bonn, A., Cooke, S. J., Frusher, S., Fulton, E. A., Halpern, B. S., Lopes, P. F. M., Milner-Gulland, E. J., Peck, M. A., Pecl, G. T., Stephenson, R. L. \& Werner, F. (2019). Ten tips for developing interdisciplinary socio-ecological researchers. Socio-Ecological Practice Research, 1, 149-161. https://doi.org/10.1007/s42532-019-00018-2

Kemp, S. P. \& Nurius, P. S. (2015). Preparing emerging doctoral scholars for transdisciplinary research: A developmental approach. Journal of Teaching in Social Work, 35, 131-150.

Lang, D. J., Wiek, A., Bergmann, M., Pim, M., Moll, P., Swilling, M. \& Thomas, C. J. (2012). Transdisciplinary research in sustainability science: Practice, principles, and challenges. Sustainability Science, 7, 25-43.

Leicht, A., Heiss, J. \& Byun, W. J. (2018). Introduction. In A. Leicht, J. Heiss \& W. J. Byun (Eds.) Issues and Trends in Education for Development. Paris: UNESCO Publishing.

Mattor, K., Betsill, M., Huayhuaca, C., Huber-Stearns, H., Jedd, T., Sternlieb, F., Bixler, P., Luizza, M. \& Cheng, A. S. (2014). Transdisciplinary research on environmental governance: A view from the inside. Environmental Science and Policy, 42, 90-100.

Mitrany, M. \& Stokols, D. (2005). Gauging the transdisciplinary qualities and outcomes of doctoral training programs. Journal of Planning Education and Research, 24, 437-449.

Mobjörk, M. (2010). Consulting versus participatory transdisciplinarity: A refined classification of transdisciplinary research. Futures, 42, 866-873.

Muhar, A., Visser, J. \& van Breda, J. (2013). Experiences from establishing structured inter- and transdisciplinary doctoral programs in sustainability: A comparison of two cases in South Africa and Austria. Journal of Cleaner Production, 61, 122-129.

O’Brien, K., Reams, J., Caspari, A., Dugmore, A., Faghihimani, M., Fazey, I., Hackmann, H., ManuelNavarrete, D., Marks, J., Miller, R., Raivio, K., Romero-Lankao, P., Virji, H., Vogel, C. \& Winiwarter, V. (2013). You say you want a revolution? Transforming education and capacity building in response to global change. Environmental Science \& Policy, 28, 48-59.

Popa, F., Guillermin, M. \& Dedeurwaerdere, T. (2014). A pragmatist approach to transdisciplinarity in sustainability research: From complex systems theory to reflexive science. Futures, 65, 45-46.

Schmidt, J. C. (2008). Towards a philosophy of interdisciplinarity: An attempt to provide a classification and clarification. Poiesis Prax, 5, 53-69.

Schneider, F. \& Rist. S. (2013). Envisioning sustainable water futures in a transdisciplinary learning process: Combining normative, explorative, and participatory scenario approaches. Sustainability Science, 9, 463-481. DOI 10.1007/s11625-013-0232-6

Scholz, R. W. \& Steiner, G. (2015). Transdisciplinarity at the crossroads. Sustainability Science, 10, 521-526. DOI: $10.1007 / \mathrm{s} 11625-015-0338-0$

Sonesson, A. \& Lindberg-Sand, Å. (2016). Forskarhandledningens ramförutsättningar. In E. Brodin, J. Lindén, A. Sonesson \& Å. Lindberg-Sand (Eds.): Forskarhandledning i teori och praktik. Lund: Studentlitteratur.

Thompson Klein, J. (1996). Crossing Boundaries: Knowledge, Disciplinarities, and Interdisciplinarities. Charlottesville: University Press of Virginia.

Thompson Klein, J. (2004). Prospects of transdisciplinarity. Futures, 35, 515-526.

Thompson Klein, J. (2014). Discourses of transdisciplinarity: Looking back to the future. Futures, 63, 68-74. 
88 Malin Mobjörk et al.

APPENDIX I: THE FOUR RESEARCH MILIEUS

\begin{tabular}{|c|c|c|c|c|}
\hline Research milieu & A & B & $\mathrm{C}$ & D \\
\hline $\begin{array}{l}\text { Main cross- } \\
\text { disciplinary } \\
\text { approach }\end{array}$ & Multidisciplinary & Interdisciplinary & $\begin{array}{l}\text { Inter- and } \\
\text { transdisciplinary }\end{array}$ & Interdisciplinary \\
\hline Faculty & $\begin{array}{l}\text { Arts and Social } \\
\text { Sciences }\end{array}$ & $\begin{array}{l}\text { Health, Science and } \\
\text { Technology }\end{array}$ & $\begin{array}{l}\text { Mathematical and } \\
\text { Natural Sciences }\end{array}$ & $\begin{array}{l}\text { Science and } \\
\text { Technology }\end{array}$ \\
\hline $\begin{array}{l}\text { No. of senior } \\
\text { researchers on } \\
\text { I January } 2016\end{array}$ & I7 & 9 & 2 & $\begin{array}{l}\text { N.A. (6 when the } \\
\text { programme was } \\
\text { running) }\end{array}$ \\
\hline $\begin{array}{l}\text { Disciplines in } \\
\text { which the senior } \\
\text { researchers hold } \\
\text { PhDs }\end{array}$ & $\begin{array}{l}\text { Historical archaeology } \\
\text { History } \\
\text { Human geography } \\
\text { Political science } \\
\text { Social work } \\
\text { Sociology }\end{array}$ & $\begin{array}{l}\text { Environmental \& energy } \\
\quad \text { systems } \\
\text { Historical archaeology } \\
\text { History } \\
\text { Hydrology } \\
\text { Physical geography } \\
\text { Political science } \\
\text { Public health sciences } \\
\text { Risk \& environmental } \\
\text { studies } \\
\text { Social medicine }\end{array}$ & $\begin{array}{l}\text { Geography/ } \\
\text { Engineering } \\
\text { Geo-ecology }\end{array}$ & $\begin{array}{l}\text { Ecology } \\
\text { Forest history } \\
\text { History } \\
\text { History of medicine } \\
\text { Political science }\end{array}$ \\
\hline $\begin{array}{l}\text { Disciplines in } \\
\text { which the senior } \\
\text { researchers } \\
\text { are currently } \\
\text { employed } \\
\text { (as of 2016) }\end{array}$ & $\begin{array}{l}\text { Environmental } \\
\text { science } \\
\text { History } \\
\text { Human geography } \\
\text { Risk \& environmental } \\
\text { studies } \\
\text { Political science } \\
\text { Social work } \\
\text { Sociology } \\
\text { Tourism studies }\end{array}$ & $\begin{array}{l}\text { Environmental science } \\
\text { Risk Management } \\
\text { Risk \& environmental } \\
\quad \text { studies }\end{array}$ & $\begin{array}{l}\text { Geography } \\
\text { Hydrology }\end{array}$ & N.A. \\
\hline $\begin{array}{l}\text { Do the senior } \\
\text { researchers' } \\
\text { bibliographies } \\
\text { include cross- } \\
\text { disciplinary } \\
\text { publications? }\end{array}$ & Yes (I4), No (3) & Yes (9) & Yes (8) & Yes (6) \\
\hline $\begin{array}{l}\text { No. of PhD } \\
\text { candidates on } \\
\text { I January } 2016\end{array}$ & I2 & IO & 8 & $\begin{array}{l}\text { N.A. ( } 4 \text { were enrolled } \\
\text { in the programme) }\end{array}$ \\
\hline $\begin{array}{l}\text { Subjects in which } \\
\text { PhDs are awarded }\end{array}$ & $\begin{array}{l}\text { History } \\
\text { Human geography } \\
\text { Political science } \\
\text { Risk \& environmental } \\
\text { studies } \\
\text { Sociology } \\
\text { Social work }\end{array}$ & $\begin{array}{l}\text { Risk \& environmental } \\
\text { studies }\end{array}$ & Geography & $\begin{array}{l}\text { Ecology } \\
\text { History } \\
\text { Political science }\end{array}$ \\
\hline
\end{tabular}




\section{APPENDIX II: INTERVIEWS WITH PHD CANDIDATES}

\section{Research milieu $A$}

PhD candidate 1 (completed PhD), face-to-face interview, 27 Aug. 2015, duration 52 minutes. $\mathrm{PhD}$ candidate 2 (ongoing PhD), face-to-face interview, 20 May 2015, duration 48 minutes. $\mathrm{PhD}$ candidate 3 (ongoing $\mathrm{PhD}$ ), face-to-face interview, 29 May 2015, duration 35 minutes.

\section{Research milieu $B$}

$\mathrm{PhD}$ candidate 1 (ongoing $\mathrm{PhD}$ ), face-to-face interview, 21 May 2015, duration 51 minutes. $\mathrm{PhD}$ candidate 2 (ongoing $\mathrm{PhD}$ ), face-to-face interview, 5 June 2015, duration 48 minutes. $\mathrm{PhD}$ candidate 3 (ongoing PhD), face-to-face interview, 19 May 2015, duration 38 minutes. $\mathrm{PhD}$ candidate 4 (ongoing $\mathrm{PhD}$ ), face-to-face interview, 16 June 2015, duration 58 minutes.

\section{Research milieu $C$}

$\mathrm{PhD}$ candidate 1 (ongoing $\mathrm{PhD}$ ), face-to-face interview, 7 May 2015, duration 32 minutes. $\mathrm{PhD}$ candidate 2 (ongoing PhD), face-to-face interview, 7 May 2015, duration 37 minutes. $\mathrm{PhD}$ candidate 3 (ongoing $\mathrm{PhD}$ ), face-to-face interview, 7 May 2015, duration 45 minutes. $\mathrm{PhD}$ candidate 4 (ongoing $\mathrm{PhD}$ ), telephone interview, 9 June 2015, duration 43 minutes.

\section{Research milieu $D$}

$\mathrm{PhD}$ candidate 1 (completed $\mathrm{PhD}$ ), face-to-face interview, 8 June 2015, duration 51 minutes. $\mathrm{PhD}$ candidate 2 (completed $\mathrm{PhD}$ ), Skype interview, 11 June 2015, duration 41 minutes.

$\mathrm{PhD}$ candidate 3 (completed $\mathrm{PhD}$ ), telephone interview, 20 May 2015, duration 39 minutes. 